\title{
Paleomagnetism of Miocene dikes in the Shitara basin and the tectonic evolution of central Honshu, Japan
}

\author{
Hiroyuki Hoshi and Miho Yokoyama \\ Department of Earth Sciences, Aichi University of Education, 1 Hirosawa, Kariya, Aichi 448-8542, Japan
}

(Received June 2, 2000; Revised March 12, 2001; Accepted March 14, 2001)

\begin{abstract}
Central Honshu, Japan, is conspicuous for a northward-convex form of zonal geologic structures. To clarify the formation of curvature of the zonal structures in the west of the convex form and further to discuss the tectonic evolution of central Honshu, we carried out a paleomagnetic study of dated ( $\sim 15 \mathrm{Ma})$ dike rocks of the Shitara basin. Samples were collected from 25 basalt dikes trending north-south with a nearly vertical intrusion surface. After stepwise alternating-field and thermal demagnetization, 24 site-mean directions were determined. Three dikes gave anomalous directions, probably resulting from instantaneous recording of a field transition or excursion. The other 21 site-means produced a mean direction, $D=9.7^{\circ}, I=54.5^{\circ}, \alpha_{95}=5.2^{\circ}$, and a paleomagnetic pole at $82.3^{\circ} \mathrm{N}, 216.6^{\circ} \mathrm{E}, A_{95}=6.2^{\circ}$. Although the reversal test is negative at the $5 \%$ significance level, the mean direction and pole are time-averaged ones in which the secular variation is averaged out. This was confirmed by studying the angular standard deviation of virtual geomagnetic poles. We conclude that the central Honshu curvature formed when the southwest Japan arc rotated clockwise between 17 and $15 \mathrm{Ma}$ in relation to the opening of the Japan Sea, associated with differential rotation of the eastern part of the arc with respect to the central part. The differential rotation probably resulted from a sinistral shear on the eastern margin of the rotating arc. The formation of the curvature seems not to have borne on the collision of the Izu-Ogasawara arc with Honshu, although the collision probably caused large-scale clockwise rotation of the Kanto Mountains in the east of the northward-convex structure.
\end{abstract}

\section{Introduction}

The southwest Japan arc has a zonal arrangement of geologic structures subparallel to its length, typically represented by the Median Tectonic Line (Fig. 1). The framework of this geologic feature has been built by longstanding accretion of oceanic materials to the edge of Eurasia due to plate subduction. The zonal arrangement runs roughly east-west, but it bends in a cusp form in central Honshu. Many geologists have tried to clarify the formation of this northward-convex structure (e.g., Matsuda, 1978; Amano, 1991; Niitsuma, 1999). The bending structure is generally attributed to the collision of the Izu-Ogasawara arc with central Honshu (Matsuda, 1978).

In the Tokai district of central Honshu, the zonal arrangement which is made of geologic belts, such as the Sanbagawa, Chichibu, and Shimanto, and boundary faults, such as the Median Tectonic Line, seems to curve from a latitudinal strike in the southwest to a longitudinal one in the northeast (Fig. 1). Previous paleomagnetic studies have dealt with the formation of the curvature and suggested that differential rotation of the Tokai and Hokuriku districts with respect to the central part of the southwest Japan arc (western Honshu including the San'in district) caused the curvature (Itoh, 1988; Itoh and Ito, 1989; Otofuji et al., 1999). However, the timing of the differential rotation has not been determined precisely

Copy right(C) The Society of Geomagnetism and Earth, Planetary and Space Sciences (SGEPSS); The Seismological Society of Japan; The Volcanological Society of Japan; The Geodetic Society of Japan; The Japanese Society for Planetary Sciences. because of the scarcity of Middle Miocene or younger paleomagnetic data. Resolving this problem would be crucial to a better understanding of the tectonic evolution of central Honshu.

Well-dated Middle Miocene basalt dikes occur in the Shitara sedimentary basin located on the north of the curvilinear Median Tectonic Line in the Tokai district (Fig. 1). The basin is filled with thick Miocene strata named the Shitara Group (Kato, 1962), intruded by numerous north-south trending igneous dikes dated at about $15 \mathrm{Ma}$ (Tsunakawa et al., 1983). In this study, the remanence in these dikes was measured to investigate when the curvature formed. We show that the dikes record a northerly or southerly remanence direction, which indicates little or no rotation in the Shitara basin since $15 \mathrm{Ma}$. On the basis of our new results as well as previously reported data, we discuss the tectonic evolution of central Honshu from a paleomagnetic point of view.

The paleomagnetism of Miocene rocks in the Shitara basin has previously been studied (Tosha and Tsunakawa, 1981; Torii, 1983). Tosha and Tsunakawa (1981) reported site-mean directions from nine dikes that yielded a mean direction $D=9.9^{\circ}, I=72.5^{\circ}, \alpha_{95}=13.3^{\circ}$. A steep inclination marked this direction and was attributed to a possible recording of a field transition or excursion. Torii (1983) collected samples from Lower Miocene sedimentary rocks and the overlying Middle Miocene volcanic rocks of the Shitara Group and unraveled a paleomagnetic rotation between them. In these studies, however, no description of 


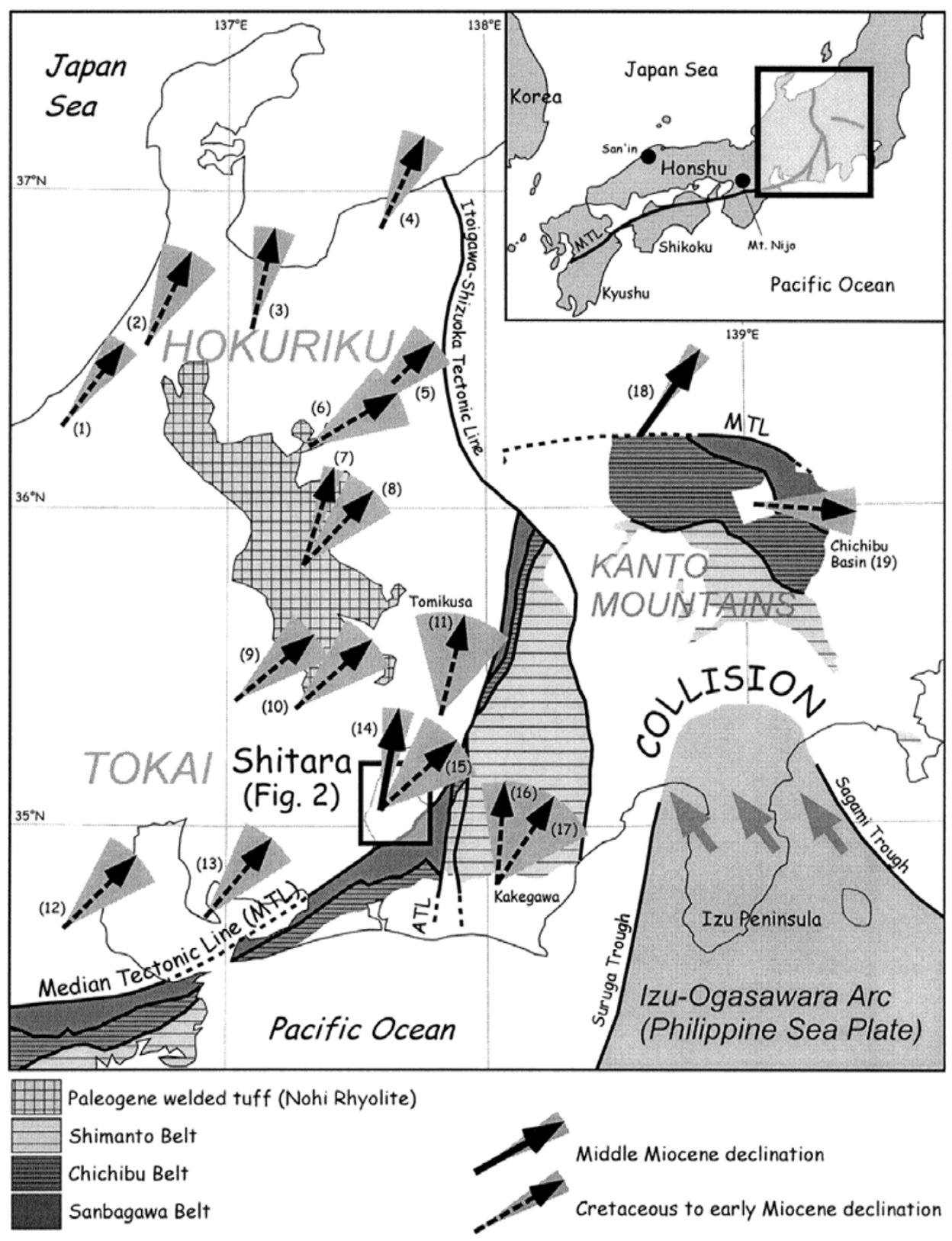

Fig. 1. Map of central Honshu showing the northward-convex form of zonal geologic structures. Also shown is location of the Shitara sedimentary basin. Paleomagnetic declinations are indicated by arrows along with the $95 \%$ confidence limits; all the paleomagnetic data shown here and their sources are summarized in the appendix (Table A1). ATL, Akaishi Tectonic Line.

tilt correction for the volcanic rocks is found, although various degrees of post-depositional tilting are actually seen in the field. For this reason the previously reported data from volcanic rocks of the Shitara Group were put aside in our tectonic consideration.

\section{Materials and Methods}

The Shitara Group is divided into the lower Hokusetsu and upper Nansetsu Subgroups (Fig. 2). The former consists mainly of Lower Miocene siliciclastic rocks, and the latter of various types of volcanic rocks of Middle Miocene age (Takada, 1988; Hoshi et al., 2000). These rocks have been intruded by numerous north-south striking dikes, which comprise several swarms; two conspicuous examples are drawn in Fig. 2. The dikes consist mainly of basalt and andesite.

Our target is a north-south striking dike swarm in the northern part of the Shitara basin (Fig. 2). Two K-Ar dates, $14.9 \pm 0.5 \mathrm{Ma}$ and $16.5 \pm 0.9 \mathrm{Ma}$, have been reported from dikes of this swarm (Tsunakawa et al., 1983). Additionally, Uchiumi et al. (1990) reported a K-Ar date of $15.0 \pm 0.7$ Ma from a basalt flow considered to be the effusive facies of the dike swarm. Based on these dates, this dike swarm formed around $15 \mathrm{Ma}$. We collected samples along streams in approximately a $0.5 \mathrm{~km}^{2}$ area (Fig. 3(a)). In this area, dikes consist of basalt with both aphyric and porphyritic textures and intrude gently $\left(\sim 10^{\circ}\right.$ or less) tilted siliciclastic sediments of the Hokusetsu Subgroup. We found 26 dikes in to- 


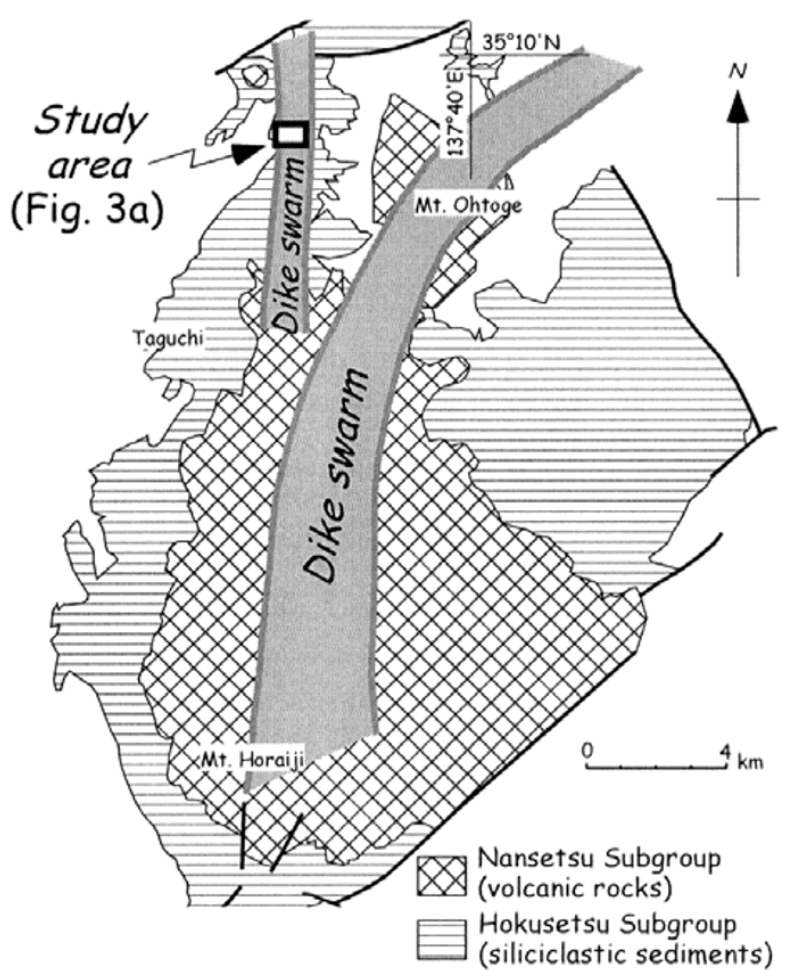

Fig. 2. Simplified geologic map of the Shitara basin showing location of the study area.

tal, and samples were collected from 25 . Of these, about one third have a fresh aspect, being black or dark gray in color, and the rest show gray or white color due to alteration. The width of the dikes ranges from 0.3 to $>30 \mathrm{~m}$. The attitudes of intrusion surfaces are summarized in Fig. 3(b), in which it should be noted that most of the intrusion surfaces are vertical or steeply inclined. In Fig. 3(b), the solid circle shows the mean pole calculated from 25 poles to the intrusion surfaces. The mean pole is indistinguishable from the horizontal east-west axis at the $95 \%$ confidence level, demonstrating vertical occurrence. Along with the gentle dip of the country strata, this suggests little tilting of dikes after intrusion. Hence, tilt correction was not made for obtained remanence directions.

More than six core samples were taken by drilling each site and oriented with a magnetic compass. In the laboratory, one or two specimens of $22 \mathrm{~mm}$ long were cut from each core sample.

Measurement was made with a $2 \mathrm{G}$ cryogenic magnetometer in a field-free space at Kyoto University and a Schonstedt spinner magnetometer at Aichi University of Education. As a pilot study, two specimens per site were chosen for a detailed stepwise demagnetization experiment by conventional thermal and alternating-field techniques. Stepwise alternating-field demagnetization (AFD) was carried out in more than 10 steps up to $110 \mathrm{mT}$, and stepwise thermal demagnetization (ThD) was done in air in more than seven steps up to $610^{\circ} \mathrm{C}$. Thermal alteration of magnetic minerals through heating was monitored by measuring magnetic susceptibility at each stage of the stepwise ThD.
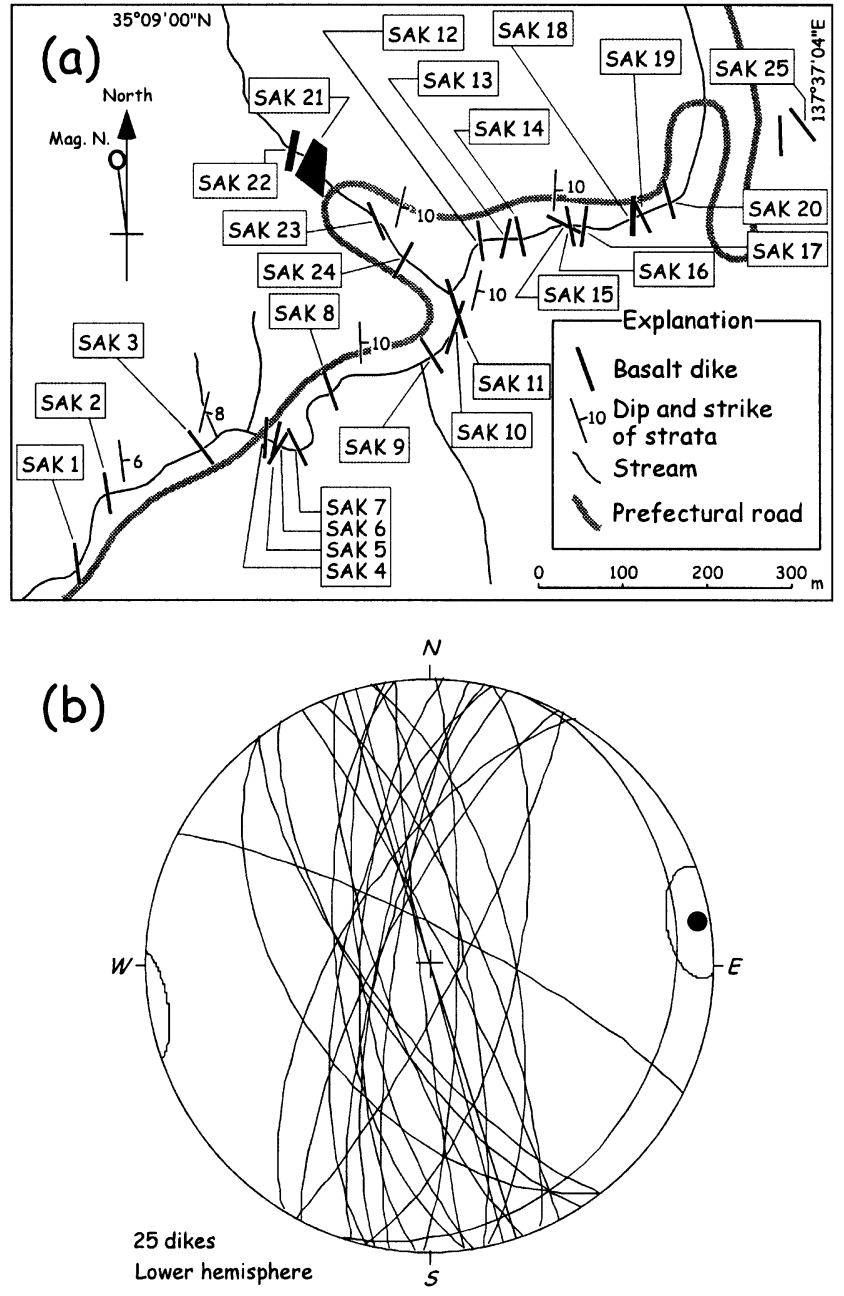

Fig. 3. (a) Geologic route map in the study area showing location of paleomagnetic sampling sites. (b) Lower-hemisphere equal-area projection of dike attitudes. The solid circle denotes the mean pole calculated from 25 poles to intrusion surfaces, and the oval about the mean pole indicates the $95 \%$ confidence region.

\section{Results}

\subsection{Paleomagnetic direction}

Examples of demagnetization results from the pilot specimens are shown in Fig. 4. Stable linear trajectories of magnetic vector endpoints were isolated from pilot specimens of 24 sites. Unstable magnetic components were successfully erased by $20 \mathrm{mT}$ or $350^{\circ} \mathrm{C}$. Many pilot specimens treated thermally showed a drastic increase in magnetic susceptibility at steps above $500^{\circ} \mathrm{C}$. This was common to altered, gray- or white-colored rocks. In such specimens, somewhat anomalous directional behaviors were found above $500^{\circ} \mathrm{C}$. For this reason the remaining specimens, except those of SAK6, were subjected to stepwise AFD, and the remaining specimens of SAK6 were treated by stepwise ThD, with the same demagnetization steps as the pilot study. The directions of stable linear trajectories were determined by fitting least-squares lines to the trajectories (Kirschvink, 1980).

SAK9 was the only site from which stable linear magnetic components were not obtained. It had the weakest NRM intensity of all the sites studied (Table 1). In addition, the AFD pilot specimen had a relatively hard viscous compo- 

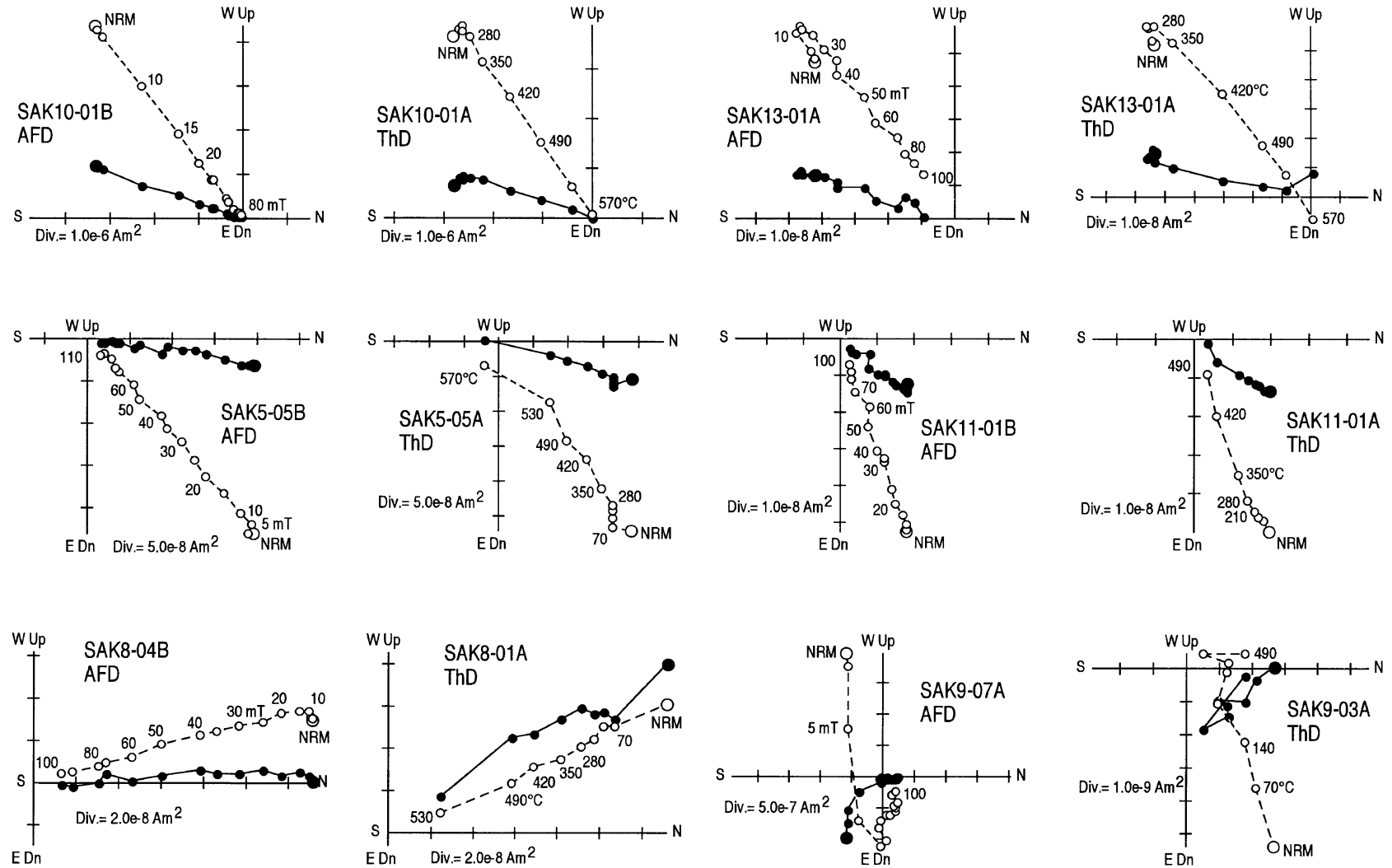

Fig. 4. Examples of stepwise demagnetization results from pilot specimens. Solid circles are vector endpoints projected onto the horizontal plane, and open circles indicate those onto the north-south vertical plane. AFD, alternating-field demagnetization; ThD, thermal demagnetization.

nent (Fig. 4). These observations are probably explained by the fact that the SAK9 samples consist of white-colored altered basalt. From the results of stepwise AFD, the primary magnetic polarity is inferred as normal.

Site-mean remanence data including statistic parameters (Fisher, 1953) are listed in Table 1 and plotted in Fig. 5. These are grouped into three based on their directions. Group A (number of sites, $N_{\mathrm{A}}=10$ ) is characterized by northerly declination and moderate inclination with normal polarity, and group $\mathrm{B}\left(N_{\mathrm{B}}=11\right)$ is characterized by southerly declination and moderate inclination with reversed polarity. Table 1 also summarizes group-mean remanence data. These two groups make a rough antipode and give a mean direction $D=9.7^{\circ}, I=54.5^{\circ}, \alpha_{95}=5.2^{\circ}(N=21)$ after inverting the reversed-polarity site-means to the normal. Group C (3 sites) is anomalous, marked by northerly declination and shallow negative inclination.

\subsection{Reversal test}

To evaluate the anti-parallelism between groups A and $\mathrm{B}$, we carried out the reversal test of McFadden and McElhinny (1990). Inverting one polarity group to another, we got an angle of $13.9^{\circ}$ between the two mean directions. This value exceeded, at the 5\% significance level, the critical angle $\left(9.0^{\circ}\right)$ determined by equation (15) of McFadden and McElhinny (1990), where the critical angle was calculated using quantities $N=21, R_{\mathrm{A}}$ (length of vector sum for group $\mathrm{A})=9.8018$, and $R_{\mathrm{B}}$ (that for group $\left.\mathrm{B}\right)=10.8245$. This result indicates failure in the reversal test.

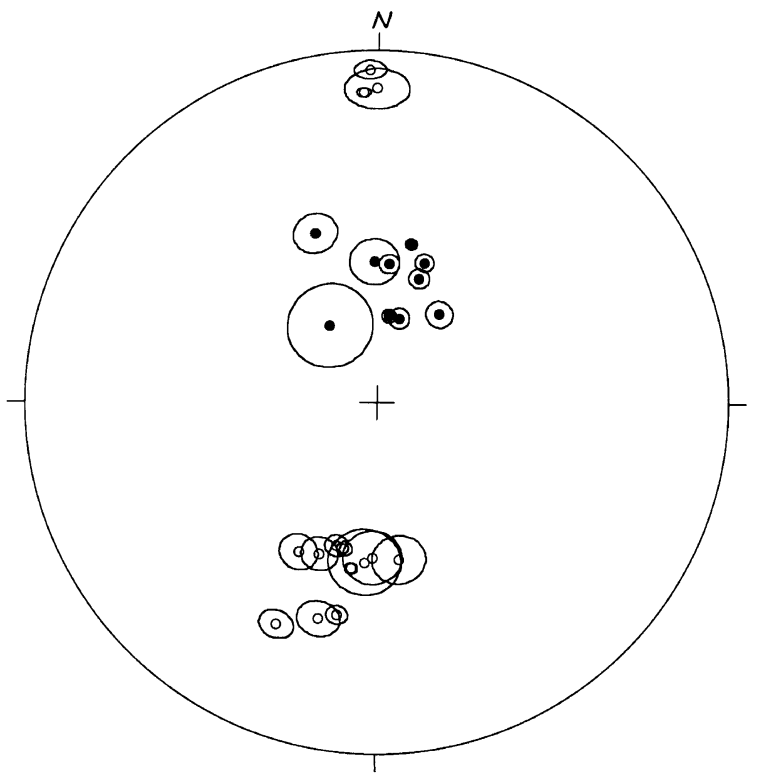

Fig. 5. Equal-area projection of site-mean remanence directions with $95 \%$ confidence ovals from 24 basalt dikes. Solid circles are directions on the lower hemisphere, and open circles are those on the upper hemisphere.

\section{Discussion}

\subsection{Cause of the negative reversal test}

The northerly declination of group $\mathrm{A}(D \pm \Delta D=$ $5.6 \pm 15.2^{\circ}$, where the $95 \%$ confidence limit $\Delta D=$ $\left.\arcsin \left(\sin \alpha_{95} / \cos I\right)\right)$ is statistically said to be anti-parallel 
Table 1. Remanence data from the Middle Miocene dikes, Shitara basin, central Honshu.

\begin{tabular}{|c|c|c|c|c|c|c|c|c|c|c|c|c|c|}
\hline \multirow[t]{2}{*}{ Site } & \multirow[t]{2}{*}{ (Lat. Long.) } & \multirow[t]{2}{*}{$S / D$} & \multirow[t]{2}{*}{$N$} & \multirow{2}{*}{$\begin{array}{c}J \\
(\mathrm{~mA} / \mathrm{m})\end{array}$} & \multirow{2}{*}{$\begin{array}{r}D \\
\left({ }^{\circ}\right) \\
\end{array}$} & \multirow{2}{*}{$\begin{array}{c}I \\
\left({ }^{\circ}\right) \\
\end{array}$} & \multirow{2}{*}{$\begin{array}{r}\alpha_{95} \\
\left({ }^{\circ}\right) \\
\end{array}$} & \multirow[t]{2}{*}{$k$} & \multicolumn{2}{|c|}{ North VGP } & \multirow{2}{*}{$\begin{array}{l}S_{l} \\
\left({ }^{\circ}\right) \\
\end{array}$} & \multirow{2}{*}{$\begin{array}{c}S \\
\left({ }^{\circ}\right)\end{array}$} & \multirow{2}{*}{$\begin{array}{l}S_{u} \\
\left(^{\circ}\right) \\
\end{array}$} \\
\hline & & & & & & & & & $\left({ }^{\circ} \mathrm{N}\right)$ & $\left({ }^{\circ} \mathrm{E}\right)$ & & & \\
\hline \multicolumn{14}{|c|}{ Directional Group A } \\
\hline SAK4 & $\left(35^{\circ} 08^{\prime} 42^{\prime \prime} \mathrm{N}, 137^{\circ} 36^{\prime} 36^{\prime \prime} \mathrm{E}\right)$ & $183 / 70$ & 7 & 18.6 & 14.6 & 69.9 & 2.4 & 657.1 & 68.7 & 161.8 & & & \\
\hline SAK5 & $\left(35^{\circ} 08^{\prime} 42^{\prime \prime} \mathrm{N}, 137^{\circ} 36^{\prime} 37^{\prime \prime} \mathrm{E}\right)$ & $193 / 65$ & 9 & 32.1 & 12.0 & 52.1 & 1.3 & 1537.9 & 79.8 & 237.9 & & & \\
\hline SAK6 & $\left(35^{\circ} 08^{\prime} 42^{\prime \prime} \mathrm{N}, 137^{\circ} 36^{\prime} 37^{\prime \prime} E\right)$ & $211 / 64$ & 9 & 20.8 & 4.8 & 57.6 & 2.3 & 492.8 & 85.1 & 187.4 & & & \\
\hline SAK11 & $\left(35^{\circ} 08^{\prime} 46^{\prime \prime} \mathrm{N}, 137^{\circ} 36^{\prime} 44^{\prime \prime} \mathrm{E}\right)$ & $162 / 90$ & 5 & 4.2 & 35.2 & 65.0 & 3.1 & 626.5 & 61.2 & 192.4 & & & \\
\hline SAK14 & $\left(35^{\circ} 08^{\prime} 50^{\prime \prime} \mathrm{N}, 137^{\circ} 36^{\prime} 48^{\prime \prime} \mathrm{E}\right)$ & $348 / 66$ & 10 & 4.2 & 18.5 & 55.6 & 2.1 & 511.2 & 75.0 & 218.4 & & & \\
\hline SAK16 & $\left(35^{\circ} 08^{\prime} 51^{\prime \prime} \mathrm{N}, 137^{\circ} 36^{\prime} 50^{\prime \prime} \mathrm{E}\right)$ & $349 / 80$ & 8 & 1.6 & 7.7 & 69.8 & 1.6 & 1255.0 & 70.7 & 151.5 & & & \\
\hline SAK17 & $\left(35^{\circ} 08^{\prime} 51^{\prime \prime} \mathrm{N}, 137^{\circ} 36^{\prime} 51^{\prime \prime} \mathrm{E}\right)$ & $188 / 80$ & 8 & 814.7 & 18.6 & 59.6 & 2.3 & 560.2 & 74.4 & 202.2 & & & \\
\hline SAK18 & $\left(35^{\circ} 08^{\prime} 51^{\prime \prime} \mathrm{N}, 137^{\circ} 36^{\prime} 53^{\prime \prime} \mathrm{E}\right)$ & $001 / 82$ & 5 & 5.8 & 339.6 & 47.6 & 4.8 & 253.5 & 71.6 & 32.9 & & & \\
\hline SAK22 & $\left(35^{\circ} 08^{\prime} 54^{\prime \prime} \mathrm{N}, 137^{\circ} 36^{\prime} 37^{\prime \prime} \mathrm{E}\right)$ & $191 / 75$ & 6 & 46.0 & 358.7 & 57.1 & 5.5 & 152.1 & 87.2 & 115.8 & & & \\
\hline SAK25 & $\left(35^{\circ} 08^{\prime} 55^{\prime \prime} \mathrm{N}, 137^{\circ} 37^{\prime} 01^{\prime \prime} \mathrm{E}\right)$ & $143 / 72$ & 5 & 1.2 & 328.3 & 69.1 & 9.8 & 61.4 & 61.6 & 95.5 & & & \\
\hline \multicolumn{2}{|c|}{ Mean direction (10 site-means) } & & & & 5.6 & 61.5 & 7.2 & 45.4 & & & & & \\
\hline \multicolumn{2}{|c|}{ Mean pole (10 VGPs) } & & & & & \multicolumn{3}{|c|}{$\left(A_{95}=10.1^{\circ}\right)$} & 80.4 & 164.3 & 12.9 & 16.7 & 23.6 \\
\hline \multicolumn{14}{|c|}{ Directional Group B } \\
\hline SAK1 & $\left(35^{\circ} 08^{\prime} 37^{\prime \prime} \mathrm{N}, 137^{\circ} 36^{\prime} 27^{\prime \prime} \mathrm{E}\right)$ & $173 / 87$ & 14 & 15.4 & 190.4 & -38.2 & 2.3 & 303.1 & 73.6 & 281.2 & & & \\
\hline SAK2 & $\left(35^{\circ} 08^{\prime} 40^{\prime \prime} \mathrm{N}, 137^{\circ} 36^{\prime} 27^{\prime \prime} \mathrm{E}\right)$ & $171 / 70$ & 6 & 28.4 & 194.8 & -36.2 & 4.5 & 219.2 & 70.1 & 272.8 & & & \\
\hline SAK3 & $\left(35^{\circ} 08^{\prime} 42^{\prime \prime} \mathrm{N}, 137^{\circ} 36^{\prime} 32^{\prime \prime} \mathrm{E}\right)$ & $143 / 50$ & 11 & 188.0 & 192.1 & -54.6 & 1.7 & 724.7 & 80.1 & 224.2 & & & \\
\hline SAK7 & $\left(35^{\circ} 08^{\prime} 42^{\prime \prime} \mathrm{N}, 137^{\circ} 36^{\prime} 38^{\prime \prime} \mathrm{E}\right)$ & $153 / 76$ & 7 & 100.9 & 188.5 & -50.2 & 1.4 & 1905.7 & 81.7 & 255.6 & & & \\
\hline SAK10 & $\left(35^{\circ} 08^{\prime} 46^{\prime \prime} \mathrm{N}, 137^{\circ} 36^{\prime} 44^{\prime \prime} \mathrm{E}\right)$ & $018 / 15$ & 7 & 537.8 & 195.3 & -54.9 & 2.6 & 538.5 & 77.5 & 221.9 & & & \\
\hline SAK12 & $\left(35^{\circ} 08^{\prime} 50^{\prime \prime} \mathrm{N}, 137^{\circ} 36^{\prime} 46^{\prime \prime} \mathrm{E}\right)$ & $173 / 63$ & 5 & 36.5 & 171.8 & -52.4 & 5.9 & 171.8 & 82.9 & 32.4 & & & \\
\hline SAK13 & $\left(35^{\circ} 08^{\prime} 50^{\prime \prime} \mathrm{N}, 137^{\circ} 36^{\prime} 47^{\prime \prime} \mathrm{E}\right)$ & $013 / 65$ & 6 & 6.8 & 200.4 & -51.7 & 4.1 & 263.3 & 72.8 & 231.2 & & & \\
\hline SAK15 & $\left(35^{\circ} 08^{\prime} 51^{\prime \prime} \mathrm{N}, 137^{\circ} 36^{\prime} 50^{\prime \prime} \mathrm{E}\right)$ & $297 / 80$ & 4 & 2.1 & 184.1 & -52.0 & 8.0 & 493.1 & 85.8 & 263.0 & & & \\
\hline SAK19 & $\left(35^{\circ} 08^{\prime} 51^{\prime \prime} \mathrm{N}, 137^{\circ} 36^{\prime} 53^{\prime \prime} \mathrm{E}\right)$ & $333 / 85$ & 5 & 47.8 & 204.1 & -31.2 & 3.6 & 442.2 & 61.8 & 261.8 & & & \\
\hline SAK20 & $\left(35^{\circ} 08^{\prime} 52^{\prime \prime} \mathrm{N}, 137^{\circ} 36^{\prime} 54^{\prime \prime} \mathrm{E}\right)$ & $165 / 90$ & 3 & 16.6 & 207.2 & -50.1 & 4.3 & 815.9 & 66.9 & 230.5 & & & \\
\hline SAK21 & $\left(35^{\circ} 08^{\prime} 53^{\prime \prime} \mathrm{N}, 137^{\circ} 36^{\prime} 38^{\prime \prime} \mathrm{E}\right)$ & $208 / 76$ & 8 & 21.8 & 181.4 & -53.2 & 6.5 & 74.0 & 88.2 & 277.4 & & & \\
\hline \multicolumn{2}{|c|}{ Mean direction (11 site-means) } & & & & 192.4 & -48.1 & 6.1 & 57.0 & & & & & \\
\hline \multicolumn{2}{|c|}{ Mean pole (11 VGPs) } & & & & & \multicolumn{3}{|c|}{$\left(A_{95}=6.3^{\circ}\right)$} & 78.5 & 252.5 & 8.7 & 11.1 & 15.4 \\
\hline \multicolumn{2}{|c|}{$\mathrm{A}+\mathrm{B}$ mean direction (21 site-means) } & & & & 9.7 & 54.5 & 5.2 & 38.0 & & & & & \\
\hline \multicolumn{2}{|c|}{$\mathrm{A}+\mathrm{B}$ mean pole (21 VGPs) } & & & & & & $5=6$ & & 82.3 & 216.6 & 12.8 & 15.6 & 20.0 \\
\hline Directiol & l Group C & & & & & & & & & & & & \\
\hline SAK8 & $\left(35^{\circ} 08^{\prime} 44^{\prime \prime} \mathrm{N}, 137^{\circ} 36^{\prime} 39^{\prime \prime} \mathrm{E}\right)$ & $161 / 75$ & 8 & 10.5 & 357.2 & -13.0 & 1.3 & 1700.1 & 48.2 & 321.8 & & & \\
\hline SAK23 & $\left(35^{\circ} 08^{\prime} 51^{\prime \prime} \mathrm{N}, 137^{\circ} 36^{\prime} 41^{\prime \prime} \mathrm{E}\right)$ & $337 / 75$ & 5 & 1.0 & 359.7 & -11.9 & 5.9 & 171.7 & 48.8 & 318.1 & & & \\
\hline SAK24 & $\left(35^{\circ} 08^{\prime} 49^{\prime \prime} \mathrm{N}, 137^{\circ} 36^{\prime} 39^{\prime \prime} E\right)$ & $028 / 82$ & 6 & 1.3 & 358.5 & -6.3 & 2.8 & 576.2 & 51.7 & 320.0 & & & \\
\hline Mean dir & ction (3 site-means) & & & & 358.5 & -10.4 & 5.8 & 455.7 & & & & & \\
\hline Mean po & $(3 \mathrm{VGPs})$ & & & & & & $5=3$ & & 49.6 & 320.0 & & & \\
\hline Other & & & & & & & & & & & & & \\
\hline SAK9 & $\left(35^{\circ} 08^{\prime} 45^{\prime \prime} \mathrm{N}, 137^{\circ} 36^{\prime} 43^{\prime \prime} E\right)$ & $148 / 70$ & 2 & 0.4 & & & & & & & & & \\
\hline
\end{tabular}

$S / D$, strike/dip of intrusion; $N$, number of specimens used for site-mean calculation; $J$, intensity of natural remanence; $D$, declination; $I$, inclination; $\alpha_{95}$, radius of $95 \%$ confidence region of site mean direction; $k$, precision parameter; VGP, virtual geomagnetic pole; $S$, angular standard deviation (ASD) of VGPs; $S_{l}$ and $S_{u}$, lower and upper 95\% confidence limits for ASD; $A_{95}$; radius of $95 \%$ confidence region of paleomagnetic pole.

to the southerly one of group $\mathrm{B}\left(D \pm \Delta D=192.4 \pm 9.2^{\circ}\right)$. In contrast, the inclination of group A $\left(I \pm \Delta I=61.5 \pm 7.2^{\circ}\right.$, where the $95 \%$ confidence limit $\left.\Delta I=\alpha_{95}\right)$ is not antiparallel to that of group B $\left(I \pm \Delta I=-48.1 \pm 6.1^{\circ}\right)$, probably leading to the failure in the reversal test. Two possibilities might exist to explain the negative result, as discussed below.

As widely known, a negative reversal test may be achieved if a remanence includes a secondary component in spite of demagnetization (Cox and Doell, 1960; McElhinny,
1973). If there remains a stable secondary component, it would bias both groups of polarity to the same direction. Assuming that both A and B groups have an inerasable component parallel or subparallel to the present geomagnetic field, it would be possible to explain the fact that the inclination does not show an anti-parallelism. In such a particular case, when one of the groups is converted to another polarity and their mean direction is then calculated, the vector sum tends to cancel out the secondary component (McElhinny, 1973). Calculating the mean of the mean directions of groups A 


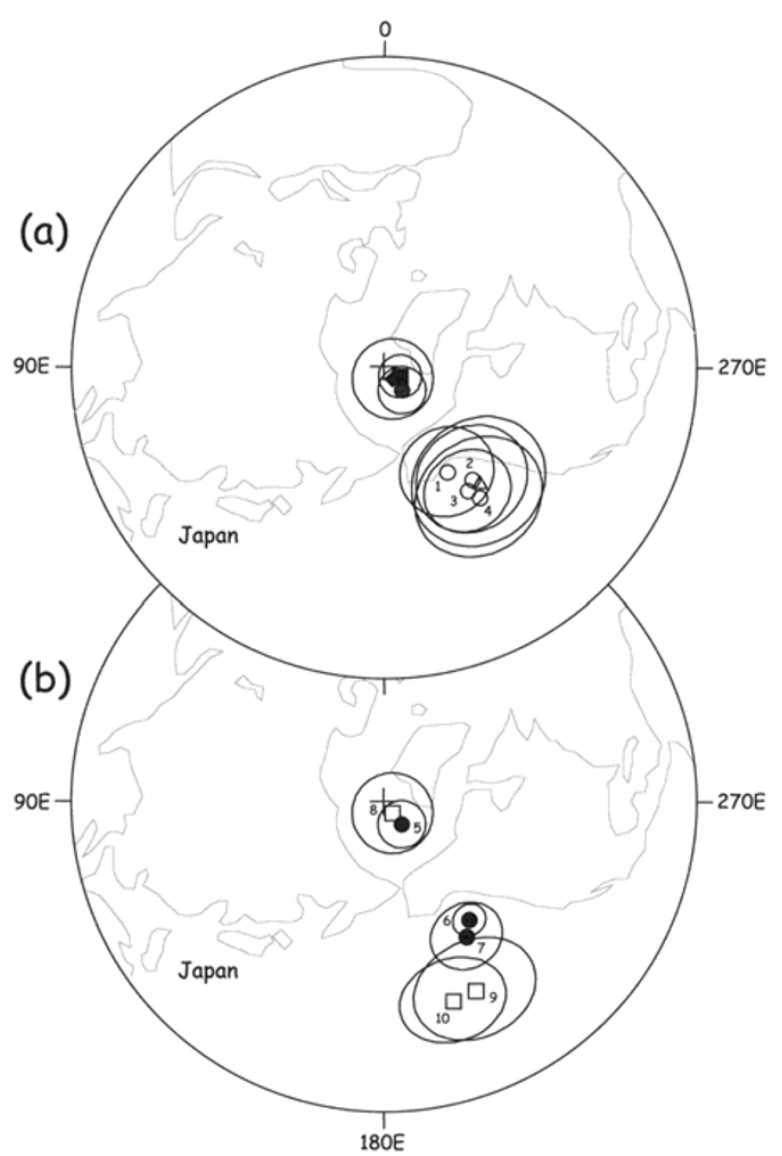

Fig. 6. Polar equal-area projections showing comparison of the paleomagnetic pole from the $\sim 15 \mathrm{Ma}$ Shitara dikes with those from other areas. Data sources are summarized in Table 2. In (a), the solid circle is the $\sim 15$ Ma Shitara pole; the solid square is the Early to Middle Miocene pole from the North China Block; the solid diamond is the $\sim 15$ Ma pole from the Omori Formation in San'in; the open triangle is the Early Miocene pole from the Hokusetsu Subgroup in the Shitara basin; and open circles are poles from the Lower Miocene series in Tokai (1, Morozaki Group; 2, Ichishi Group; 3, Kani Group; 4, Mizunami Group). In (b), solid circles are poles from Tokai (5, $\sim 15$ Ma Shitara dikes; 6, Early Miocene mean calculated from data from the Hokusetsu, Morozaki, Ichishi, Kani, and Mizunami Groups; 7, Paleogene Nohi Rhyolite); and open squares are poles from San'in ( $8, \sim 15$ Ma Omori Formation; 9 , Early Miocene Hata Formation; 10, Paleogene Sakurae Group). 95\% confidence limits with radius $A_{95}$ are shown surrounding each mean pole.

and $\mathrm{B}$, we get a direction of $D=9.6^{\circ}$ and $I=54.8^{\circ}$, which is almost identical with the mean direction from 21 site-mean directions of groups A and B (Table 1). We believe secondary components have been erased effectively by thorough stepwise demagnetization (Fig. 4), but, even if an inerasable secondary component still exists, the mean direction determined from the 21 site-means probably represents a paleomagnetic direction in the study area at about $15 \mathrm{Ma}$.

A negative reversal test can also be produced if a mean direction does not average out the secular variation thoroughly. Our result includes both normal and reversed polarities and hence samples at least a time span of one polarityreversal; nevertheless, this possibility should be examined carefully. We thus tested this by studying the angular standard deviation (ASD) of virtual geomagnetic poles (VGPs). Following Cox (1969), the 21 VGPs of groups A and B gave an ASD of $15.6^{\circ}$ with lower and upper $95 \%$ confidence lim-
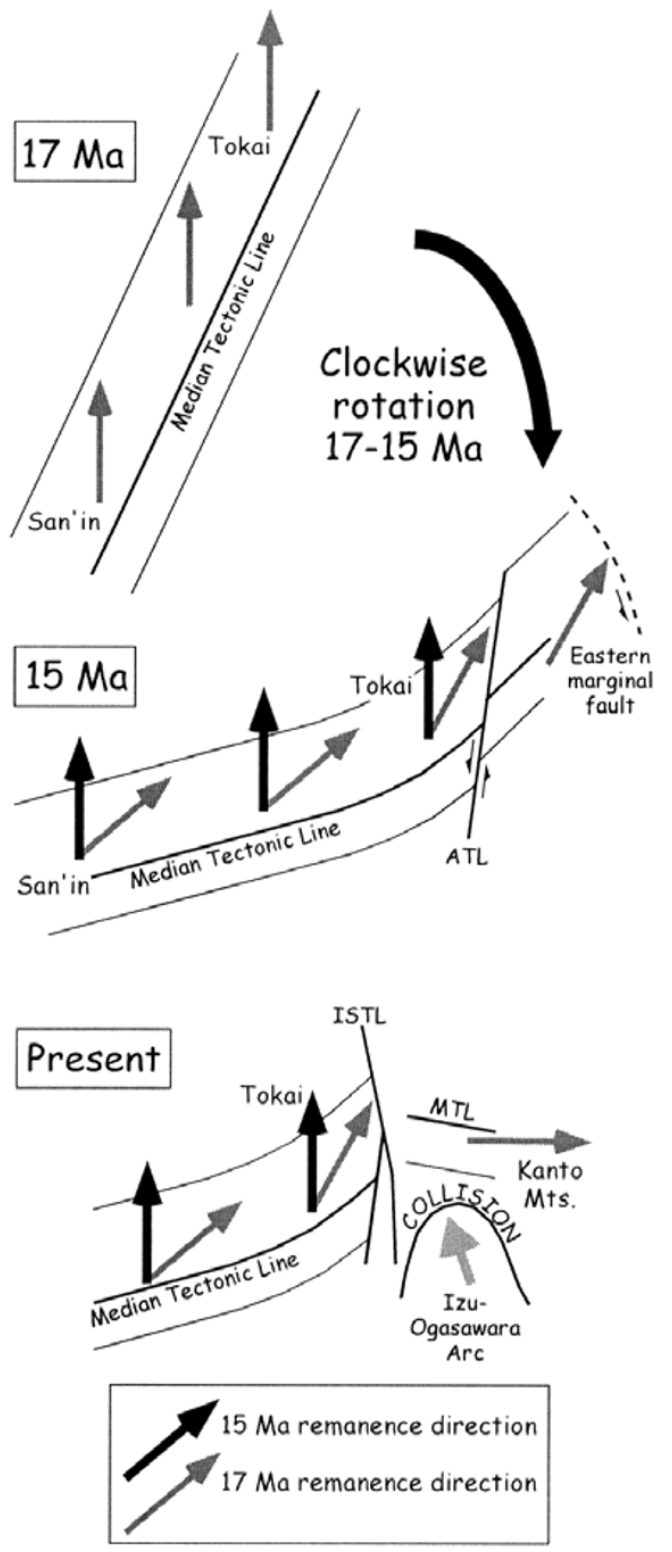

Fig. 7. Model for the clockwise rotation of the southwest Japan arc and the formation of curvature of the zonal geologic arrangement at the eastern part of the arc.

its $\left(S_{l}\right.$ and $\left.S_{u}\right)$ of $12.8^{\circ}$ and $20.0^{\circ}$, respectively. This ASD value is quite similar to the $0-5 \mathrm{Ma}$ global trend $\left(15.74^{\circ}\right.$, $S_{l}=15.08^{\circ}, S_{u}=16.46^{\circ}$ ) obtained for the latitude range $35.0-39.9^{\circ} \mathrm{N}$ from a worldwide database (McElhinny and McFadden, 1997). Therefore, we consider the mean direction determined from the 21 site-means is a paleomagnetic direction in which the secular variation is adequately averaged out, so this possibility can be discarded. In this connection, the group $\mathrm{C}$ remanence is probably an instantaneous recording of the past field because of its very small dispersion (Table 1). Remanence acquisition during a field transition or excursion could have resulted in its anomalous direction.

\subsection{Tectonic implications}

A northerly declination and an inclination similar to that expected in the geocentric axial dipole field $\left(54.6^{\circ}\right)$ mark 
Table 2. Summary of the paleomagnetic poles shown in Fig. 6.

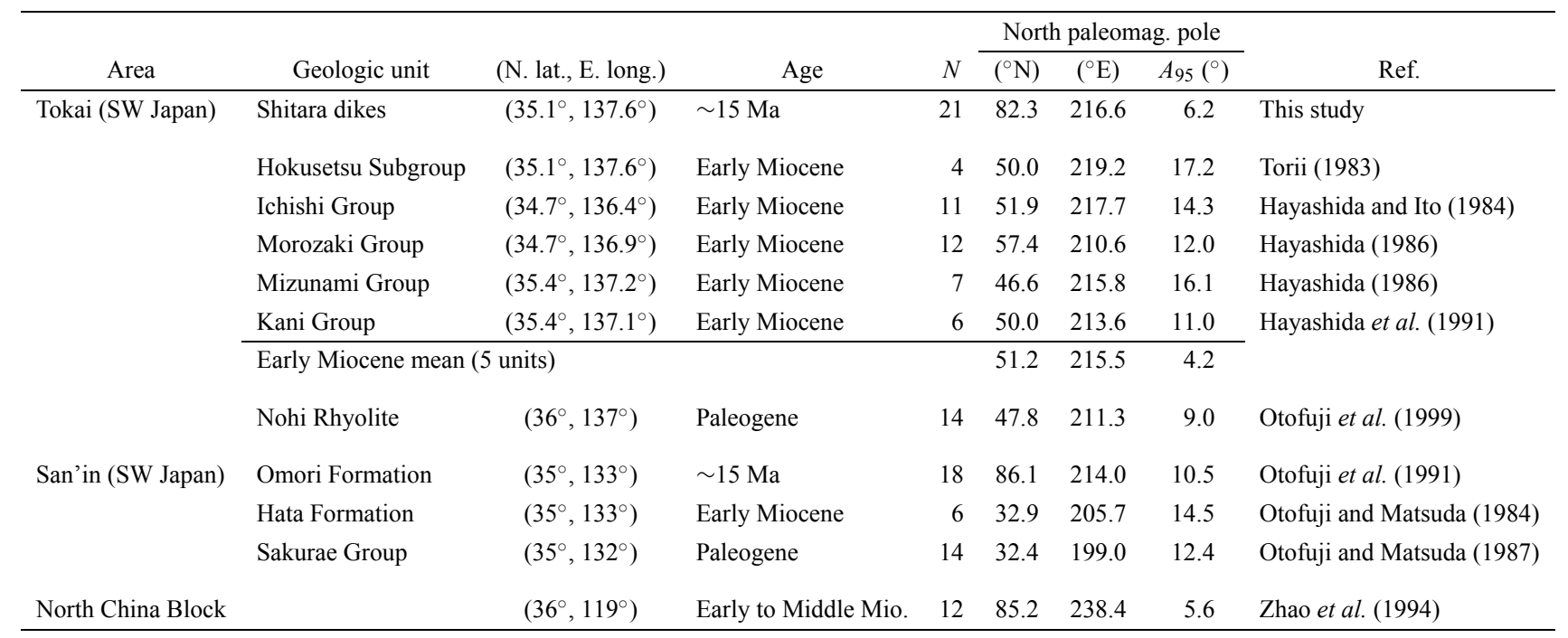

$N$, number of virtual geomagnetic poles used to calculate paleomagnetic pole; $A_{95}$, radius of $95 \%$ confidence region of paleomagnetic pole.

the mean direction of groups A and B (Table 1), suggesting little or no tectonic motion in the study area. To examine this quantitatively, we compared the paleomagnetic pole from the dikes studied with those from the other areas (Table 2 and Fig. 6). The north paleomagnetic pole from the Shitara dikes $\left(82.3^{\circ} \mathrm{N}, 216.6^{\circ} \mathrm{E}\right.$, and $\left.A_{95}=6.2^{\circ}\right)$ is plotted in Fig. 6(a) by the solid circle; also plotted are the Early to Middle Miocene paleomagnetic pole from the North China Block (NCB) in the Asian continent (Zhao et al., 1994) (solid square) and the $\sim 15 \mathrm{Ma}$ pole from the Omori Formation of the San'in district in the central part of the southwest Japan arc (Otofuji et al., 1991) (solid diamond). These pole positions are indistinguishable from each other, which indicates no paleomagnetically detectable rotation and poleward movement in the southwest Japan arc since about $15 \mathrm{Ma}$.

On the other hand, Early to Middle Miocene clockwise rotation is inferred in the Tokai district. The paleomagnetic pole from the Lower Miocene Hokusetsu Subgroup in the Shitara basin (Torii, 1983) is plotted in Fig. 6(a) by the open triangle. Despite a relatively large $95 \%$ confidence limit, it differs significantly from those from both the Shitara dikes and the NCB. However, it is in turn indistinguishable from Early Miocene poles from Tokai (shown by open circles in Fig. 6(a)). No significant difference is found among the Early Miocene poles, giving a grand-mean pole at $51.2^{\circ} \mathrm{N}, 215.5^{\circ} \mathrm{E}, A_{95}=4.2^{\circ}$. Recent biostratigraphic studies (Ito et al., 1999; Hoshi et al., 2000) showed that the Lower Miocene groups in Tokai are correlated to the diatom Crucidenticula sawamurae Zone that spans between nearly the base of chron C5D ( $\sim 18 \mathrm{Ma})$ and the middle of chron C5C ( $\sim 17 \mathrm{Ma})$ on the geomagnetic polarity time scale (Yanagisawa and Akiba, 1998). Following Demarest (1983), we get a clockwise rotation $R \pm \Delta R=38 \pm 7^{\circ}$ to account for the difference between the position of the Shitara dikes pole and that of the Early Miocene grand-mean pole. Thus, $\sim 40^{\circ}$ clockwise rotation occurred in Tokai between the deposition of the Lower Miocene groups (18-17 Ma) and about $15 \mathrm{Ma}$.

In the southwest Japan arc, differential rotation of its eastern part including the Tokai and Hokuriku districts with respect to its central part including the San'in district has been documented (Itoh, 1988; Itoh and Ito, 1989; Otofuji et al., 1999). Paleomagnetic poles from Tokai and San'in are summarized in Table 2 and shown in Fig. 6(b). In Fig. 6(b), poles from Tokai are shown by solid circles $(5=\sim 15$ Ma pole from the Shitara dikes, $6=$ Early Miocene grand-mean pole describe above, 7 = Paleogene pole from the Nohi Rhyolite reported by Otofuji et al. (1999)), and those from San'in are shown by open squares $(8=\sim 15$ Ma pole from the Omori Formation, $9=$ Early Miocene pole from the Hata Formation (Otofuji and Matsuda, 1984), 10 = Paleogene pole from the Sakurae Group (Otofuji and Matsuda, 1987)). In each district, no significant difference is found between the Early Miocene pole and the Paleogene one. However, there is a difference between the Early Miocene and Paleogene poles of Tokai (6 and 7 in Fig. 6(b)) and those of San'in (9 and 10), in spite of the almost identical position at about $15 \mathrm{Ma}$ (5 and 8). Comparison of poles shows a clockwise rotation $R \pm \Delta R=65 \pm 17^{\circ}$ in San'in between $\sim 20 \mathrm{Ma}$ (age of the Hata Formation: Otofuji and Matsuda, 1984) and $\sim 15 \mathrm{Ma}$ (Omori Formation). This amount of rotation is $27^{\circ}$ larger than in Tokai. Thus, as Itoh (1988), Itoh and Ito (1989), and Otofuji et al. (1999) pointed out, the eastern part of the southwest Japan arc rotated counterclockwise with respect to the central part. Our results from the Shitara dikes constrain the timing of this differential rotation; the rotation had ceased by about $15 \mathrm{Ma}$.

The Early to Middle Miocene clockwise rotation in Tokai and San'in is attributed to the clockwise rotation of the southwest Japan arc associated with the opening of the Japan Sea (Torii, 1983; Otofuji et al., 1991; Hayashida et al., 1991). The precise timing of the clockwise rotation has been at issue, but our data suggest that the rotation had ceased by about $15 \mathrm{Ma}$. We feel that more data are needed to enhance 
Table A1. Summary of the paleomagnetic directional data shown in Fig. 1. Numbers (No.) correspond to those in Fig. 1.

\begin{tabular}{|c|c|c|c|c|c|c|c|c|}
\hline No. & Area & (N. lat., E. long.) & Age & $\begin{array}{c}D \\
\left(^{\circ}\right) \\
\end{array}$ & $\begin{array}{c}d D \\
\left(^{\circ}\right)\end{array}$ & $\begin{array}{c}I \\
\left(^{\circ}\right) \\
\end{array}$ & $\begin{array}{r}\alpha_{95} \\
\left({ }^{\circ}\right)\end{array}$ & Ref. \\
\hline 1 & Daishoji & $\left(36.3^{\circ}, 136.3^{\circ}\right)$ & Early Mio. & 36.5 & 10.2 & 53.9 & 6.0 & Itoh and Ito (1989) \\
\hline 2 & Kanazawa & $\left(36.5^{\circ}, 136.7^{\circ}\right)$ & Early Mio. & 25.6 & 17.0 & 49.3 & 11.0 & Itoh and Ito (1989) \\
\hline 3 & Yatsuo & $\left(36.6^{\circ}, 137.1^{\circ}\right)$ & Early Mio. & 13.0 & 11.9 & 52.7 & 7.2 & Itoh (1988) \\
\hline 4 & Uozu & $\left(36.8^{\circ}, 137.5^{\circ}\right)$ & Paleogene & 25.2 & 13.4 & 55.6 & 7.5 & Itoh and Ito (1988) \\
\hline 5 & Kasagatake & $\left(36^{\circ}, 137^{\circ}\right)$ & Paleogene & 45.8 & 14.6 & 40.1 & 11.1 & Otofuji et al. (1999) \\
\hline 6 & Oamamiyama & $\left(36^{\circ}, 137^{\circ}\right)$ & Late Cret. & 58.9 & 18.8 & 61.7 & 8.8 & Otofuji et al. (1999) \\
\hline 7 & Nohi & $\left(36^{\circ}, 137^{\circ}\right)$ & Late Cret. & 17.0 & 9.5 & 49.8 & 6.1 & Itoh $(1988)$ \\
\hline 8 & Nohi & $\left(36^{\circ}, 137^{\circ}\right)$ & Late Cret. & 43.0 & 16.4 & 51.5 & 10.1 & Otofuji et al. (1999) \\
\hline 9 & Kani & $\left(35.4^{\circ}, 137.1^{\circ}\right)$ & Early Mio. & 49.9 & 16.3 & 53.2 & 9.7 & Hayashida et al. (1991) \\
\hline 10 & Mizunami & $\left(35.4^{\circ}, 137.2^{\circ}\right)$ & Early Mio. & 48.4 & 17.9 & 48.3 & 11.8 & Hayashida (1986) \\
\hline 11 & Tomikusa & $\left(35.3^{\circ}, 137.8^{\circ}\right)$ & Early Mio. & 13.4 & 27.9 & 55.4 & 15.4 & Hayashida (1992) \\
\hline 12 & Ichishi & $\left(34.7^{\circ}, 136.4^{\circ}\right)$ & Early Mio. & 45.1 & 18.2 & 48.8 & 11.9 & Hayashida and Ito (1984) \\
\hline 13 & Morozaki & $\left(34.7^{\circ}, 136.9^{\circ}\right)$ & Early Mio. & 40.3 & 17.3 & 55.5 & 9.7 & Hayashida (1986) \\
\hline 14 & Shitara & $\left(35.1^{\circ}, 137.6^{\circ}\right)$ & Middle Mio. & 9.7 & 9.0 & 54.5 & 5.2 & This study \\
\hline 15 & Shitara & $\left(35.1^{\circ}, 137.6^{\circ}\right)$ & Early Mio. & 48.0 & 22.1 & 50.0 & 14.0 & Torii (1983) \\
\hline 16 & Kakegawa & $\left(34.8^{\circ}, 138.0^{\circ}\right)$ & Early Mio. & 4.4 & 12.5 & 59.6 & 6.3 & Hayashida (1994) \\
\hline 17 & Kakegawa & $\left(34.8^{\circ}, 138.0^{\circ}\right)$ & Early Mio. & 32.7 & 29.3 & 58.3 & 14.9 & Hiroki and Matsumoto (1999) \\
\hline 18 & Uchiyama & $\left(36.3^{\circ}, 138.6^{\circ}\right)$ & Middle Mio. & 34.7 & 7.0 & 51.2 & 4.4 & Takahashi and Watanabe (1993) \\
\hline 19 & Chichibu & $\left(36.0^{\circ}, 139.0^{\circ}\right)$ & Early Mio. & 93.7 & 13.8 & 52.7 & 8.3 & Hyodo and Niitsuma (1986) \\
\hline
\end{tabular}

$D$, declination; $d D, 95 \%$ confidence limit for declination; $I$, inclination; $\alpha_{95}$, radius of $95 \%$ confidence region of mean direction.

the reliability of age of the Shitara dikes, but the age of 15 $\mathrm{Ma}$ as the upper limit is strengthened by a recent result by Hoshi et al. (2000). They dated a northerly remanence in volcanic rocks of the Mt. Nijo area at $14.6 \mathrm{Ma}$ or older by magnetostratigraphic dating. Most of the clockwise rotation of the southwest Japan arc probably occurred between 17 and $15 \mathrm{Ma}$.

Figure 7 illustrates a model for the clockwise rotation of the southwest Japan arc and intra-arc differential rotation. The clockwise rotation and differential rotation took place simultaneously between 17 and $15 \mathrm{Ma}$. The differential rotation resulted in the formation of curvature of the zonal geologic arrangement. Macroscopically, the deformation in the eastern part of the southwest Japan arc was probably in a ductile manner (Itoh and Ito, 1989). Otofuji et al. (1999) pointed out that the Akaishi Tectonic Line (ATL) acted as a major boundary fault, with which we fundamentally agree. Left-lateral movement along the ATL at about 15 Ma probably caused local rotation that affected an initially northeasterly Early Miocene remanence in Tomikusa to become a less deflected one (Hayashida, 1992) (Fig. 1). Conflicting results have been reported from Lower Miocene sediments of Kakegawa (Hayashida, 1994; Hiroki and Matsumoto, 1999); a northerly remanence was reported by Hayashida (1994), while we can get a northeasterly mean direction by adopting only the reversed-polarity site-means determined by Hiroki and Matsumoto (1999). Most of the site-means of normal polarity measured by Hiroki and Matsumoto (1999) have a direction close to the geocentric axial dipole field direction in situ, so they would be affected by a viscous component. We feel further paleomagnetic studies are needed for Kakegawa, and in the model we leave the Kakegawa data out of consideration.

Two different possibilities for the cause of the differential rotation have been illustrated (Itoh, 1988). One is that left-lateral shear produced on the eastern margin of the rotating southwest Japan arc resulted in a counterclockwise rotation of the eastern part of the southwest Japan arc relative to the central part. Another interpretation is that the Izu-Ogasawara arc collided with central Honshu, causing counterclockwise rotation of the region west of the ISTL and clockwise rotation of the Kanto Mountains. In the Kanto Mountains, a more than $90^{\circ}$ clockwise rotation is inferred to have occurred since the Early Miocene (Hyodo and Niitsuma, 1986). Half of this rotation could have resulted from the clockwise rotation of the southwest Japan arc and the rest occurred after $12 \mathrm{Ma}$, probably related to the collision of the Izu-Ogasawara arc (Takahashi and Watanabe, 1993). Geologic observations suggest multiple collision events of buoyant crustal masses of the Izu-Ogasawara arc since at least Middle Miocene time (Amano, 1991). However, our model indicates that the formation of curvature of the zonal geologic arrangement west of the ISTL was not related to the Middle Miocene or later collision of the IzuOgasawara arc. The simultaneity of the differential rotation with the clockwise rotation of the southwest Japan arc strongly suggests the formation of the curvature associated with the sinistral shear produced on the eastern margin of the rotating arc. Intra-arc differential rotation also occurred in the western part of the southwest Japan arc during the opening of the Japan Sea (Ishikawa, 1997); about $30^{\circ}$ counterclockwise rotation of northern Kyushu relative to the central part of the arc is suggested from paleomagnetic data. 


\section{Conclusions}

The paleomagnetism of Middle Miocene dikes in the Shitara basin leads us to conclude that the curvature of the zonal geologic arrangement in the west of the cusp structure in central Honshu formed when the southwest Japan arc rotated clockwise between 17 and $15 \mathrm{Ma}$. This deformation was associated with differential rotation of the eastern part of the southwest Japan arc with respect to the central part that probably resulted from the sinistral shear on the eastern margin of the rotating arc. The Middle Miocene or later collision of the Izu-Ogasawara arc with Honshu seems not to have caused the curvature in the west of the cusp structure, although it caused the Kanto Mountains in the east to rotate clockwise.

Acknowledgments. We thank N. Ishikawa (Kyoto University) for his generosity in allowing us to use his paleomagnetic laboratory. M. Tamai (Kyoto University) and T. Miwa (Aichi University of Education) assisted during various stages of the laboratory measurement. Y. Yokoyama (Horaiji Natural Museum) provided geological information that was helpful to our study. Comments and suggestions from K. Uno (Kobe University), B. Huang (Chinese Academy of Sciences), and H. Tanaka (Kochi University) were very useful in improving the manuscript. This study was supported in part by Grants in Aid for Scientific Research from the Ministry of Education of Japan (no. 11740279) and the Sasakawa Scientific Research Grant from the Japan Science Society (no. 11-093).

\section{Appendix}

The data shown in Fig. 1 are listed in Table A1.

\section{References}

Amano, K., Multiple collision tectonics of the South Fossa Magna in central Japan, Modern Geol., 15, 315-329, 1991.

Cox, A., Confidence limits for the precision parameter $k$, Geophys. J. R. Astr. Soc., 18, 545-549, 1969.

Cox, A. and R. R. Doell, Review of paleomagnetism, Bull. Geol. Soc. Am., 71, 645-768, 1960.

Demarest, H. H., Jr., Error analysis for the determination of tectonic rotation from paleomagnetic data, J. Geophys. Res., 88, 4321-4328, 1983.

Fisher, R., Dispersion on a sphere, Proc. R. Soc. London, Ser. A, 217, 295 $305,1953$.

Hayashida, A., Timing of rotational motion of Southwest Japan inferred from paleomagnetism of the Setouchi Miocene Series, J. Geomag. Geoelectr., 38, 295-310, 1986.

Hayashida, A., Paleomagnetic data from the Lower Miocene Tomikusa Group, central Japan, Bull. Mizunami Fossil Mus., 19, 67-74, 1992 (in Japanese with English abstract).

Hayashida, A., Paleomagnetism of Miocene sedimentary rocks in the Kakegawa area and implication for tectonic rotation in central Japan, J. Geomag. Geoelectr., 46, 1051-1066, 1994.

Hayashida, A. and Y. Ito, Paleoposition of Southwest Japan at $16 \mathrm{Ma}$ : Implication from paleomagnetism of the Miocene Ichishi Group, Earth Planet. Sci. Lett., 68, 335-342, 1984.

Hayashida, A., T. Fukui, and M. Torii, Paleomagnetism of the Early Miocene Kani Group in Southwest Japan and its implication for the opening of the Japan Sea, Geophys. Res. Lett., 18, 1095-1098, 1991.

Hiroki, Y. and R. Matsumoto, Magnetostratigraphic correlation of Miocene regression-and-transgression boundaries in central Honshu, Japan, J. Geol. Soc. Japan, 105, 87-107, 1999.

Hoshi, H., N. Ito, and I. Motoyama, Geology, radiolarians, and geologic age of the Hokusetsu Subgroup in the Shitara area, Aichi Prefecture, central Japan, J. Geol. Soc. Japan, 106, 713-726, 2000 (in Japanese with English abstract).

Hoshi, H., D. Tanaka, M. Takahashi, and T. Yoshikawa, Paleomagnetism of the Nijo Group and its implication for the timing of clockwise rotation of Southwest Japan, J. Mineral. Petr. Sci. 95, 203-215, 2000.

Hyodo, H. and N. Niitsuma, Tectonic rotation of the Kanto Mountains, related with the opening of the Japan Sea and collision of the Tanzawa Block since middle Miocene, J. Geomag. Geoelectr., 38, 335-348, 1986.
Ishikawa, N., Differential rotations of north Kyushu Island related to middle Miocene clockwise rotation of SW Japan, J. Geophys. Res., 102, 1772917745, 1997.

Ito, C., T. Irizuki, and M. Iwai, Diatom zonal key species and geologic ages of the Miocene Morozaki, Iwamura and Tomikusa Groups in the First Setouchi Province, central Japan, J. Geol. Soc. Japan, 105, 152-155, 1999 (in Japanese with English abstract).

Itoh, Y., Differential rotation of the eastern part of southwest Japan inferred from paleomagnetism of Cretaceous and Neogene rocks, J. Geophys. Res., 93, 3401-3411, 1988.

Itoh, Y. and H. Ito, Tertiary rotational movement of the eastern part of Southwest Japan: Paleomagnetism and fission track dating of the Futomiyama Group in the Uozu area, Toyama Prefecture, Japan, J. Geol. Soc. Japan, 94, 11-18, 1988 (in Japanese with English abstract).

Itoh, Y. and Y. Ito, Confined ductile deformation in the Japan arc inferred from paleomagnetic studies, Tectonophys., 167, 57-73, 1989.

Kato, Y., On the structural development of the Shidara basin, J. Earth Sci. Nagoya Univ., 10, 51-69, 1962.

Kirschvink, J. L., The least squares line and plane and the analysis of palaeomagnetic data, Geophys. J. R. Astr. Soc., 62, 699-718, 1980.

Matsuda, T., Collision of the Izu-Bonin arc with central Honshu: Cenozoic tectonics of the Fossa Magna, Japan, J. Phys. Earth, 26, Suppl., 409421, 1978.

McElhinny, M. W., Palaeomagnetism and Plate Tectonics, 358 pp., Cambridge Univ. Press, Cambridge, 1973.

McElhinny, M. W. and P. L. McFadden, Paleosecular variation over the past 5 Myr based on a new generalized database, Geophys. J. Int., 131, 240-252, 1997.

McFadden, P. L. and M. W. McElhinny, Classification of the reversal test in palaeomagnetism, Geophys. J. Int., 103, 725-729, 1990.

Niitsuma, N., Rupture and delamination of arc crust rupture and delamination of island arc crust due to the arc-arc collision in the South Fossa Magna, central Japan, The Island Arc, 8, 441-458, 1999.

Otofuji, Y. and T. Matsuda, Timing of rotational motion of Southwest Japan inferred from paleomagnetism, Earth Planet. Sci. Lett., 70, 373-382, 1984.

Otofuji, Y. and T. Matsuda, Amount of clockwise rotation of Southwest Japan - fan shaped opening of the southwestern part of the Japan Sea, Earth Planet. Sci. Lett., 85, 289-301, 1987.

Otofuji, Y., T. Itaya, and T. Matsuda, Rapid rotation of southwest Japanpalaeomagnetism and K-Ar ages of Miocene volcanic rocks of southwest Japan, Geophys. J. Int., 105, 397-405, 1991.

Otofuji, Y., R. Enami, M. Yokoyama, K. Kamiya, S. Kuma, H. Saito, and T. Matsuda, Miocene clockwise rotation of southwest Japan and formation of curvature of the Median Tectonic Line: Paleomagnetic implications, J. Geophys. Res., 104, 12895-12907, 1999.

Takada, A., Subvolcanic structure of the central dike swarm associated with the ring complexes in the Shitara district, central Japan, Bull. Volcanol., 50, 106-118, 1988.

Takahashi, M. and Y. Watanabe, Paleomagnetism of the Miocene igneous rocks in the Uchiyama area, central Japan, J. Geomag. Geoelectr., 45, 89-101, 1993.

Torii, M., Paleomagnetism of Miocene rocks in the Setouchi Province: Evidence for rapid clockwise rotation of Southwest Japan at middle Miocene time, 126 pp., Doctoral Dissertation, Kyoto Univ., Kyoto, 1983.

Tosha, T. and H. Tsunakawa, Paleomagnetism of the Shidara dike swarm, central Japan - an estimation of paleointensity in Miocene, Rock Mag. Paleogeophys., 8, 28-33, 1981.

Tsunakawa, H., Y. Kobayashi, and A. Takada, K-Ar ages of dikes in Southwest Japan, Geochem. J., 17, 265-268, 1983.

Uchiumi, S., K. Uto, and K. Shibata, K-Ar age results-3-New data from the Geological Survey of Japan, Bull. Geol. Surv. Japan, 41, 567-575, 1990 (in Japanese with English abstract).

Yanagisawa, Y. and F. Akiba, Refined Neogene diatom biostratigraphy for the northwest Pacific around Japan, with an introduction of code numbers for selected diatom biohorizons, J. Geol. Soc. Japan, 104, 395-414, 1998.

Zhao, X., R. Coe, Y. Zhou, S. Hu, H. Wu, G. Kuang, Z. Dong, and J. Wang, Tertiary paleomagnetism of North and South China and a reappraisal of late Mesozoic paleomagnetic data from Eurasia: Implications for the Cenozoic tectonic history of Asia, Tectonophys., 235, 181-203, 1994.

H. Hoshi (e-mail: hoshi@auecc.aichi-edu.ac.jp) and M. Yokoyama 